\title{
ANALISIS DANA TALANGAN HAJI \\ BERDASARKAN FATWA NO.29 / DSN-MUI / VI / 2002 \\ (Studi Kasus Pada BPRS Dana Mulia Surakarta)
}

\author{
Muhammad Tho'in ${ }^{1}$ dan Iin Emy Prastiwi ${ }^{2}$ \\ STIE-AAS Surakarta \\ ${ }^{1}$ Email: thoinsyakira@yahoo.com \\ ${ }^{2}$ Email: iinemyprastiwi24@gmail.com
}

\begin{abstract}
Recently, there are many Islamic Finance Institutions (LKS) offer a product to help moslem to register for the fortfcoming haji session although they didn't have enough money. This product is called "Dana Talangan Haji". BPRS Dana Mulia uses ijarah multijasa contract for giving hajj credit. So that, researcher interested to take a research about the Implementation of Hajj credit financing at BPRS Dana Mulia.

The aim of the research is to know the Implementation of Hajj credit financing at BPRS Dana Mulia and to analyze the relevance with DSN-MUI Fatwa No.29/DSNMUI/VI/2002 about Hajj Credit Financing by Islamic Finance Institutions (LKS). The kinds of this research is field research. While the method used for collecting data consist of observation, interview and documentation. For the analisis technique, researcher uses descriptive qualitative approach.

From this research, researcher finds that the implementation of Hajj Credit financing at BPRS Dana Mulia Surakarta is not relevant with Fatwa No.29/DSN-MUI/VI/2002 about Hajj Credit Financing by Islamic Finance Institutions (LKS) because BPRS Dana Mulia uses ijarah multijasa contract that based on fatwa DSN-MUI NO. 44/DSN-MUI/VIII/2004 about multijasa financing.
\end{abstract}

Keywords: Islamic Finance Institutions (LKS), ijarah multijasa, fatwa

\section{PENDAHULUAN}

Begitu besarnya jumlah masyarakat Indonesia yang ingin menunaikan ibadah haji, membuat antrian yang cukup lama karena kuota juga dibatasi. Seseorang bisa mendaftar haji, dan berangkat lima sampai sepuluh tahun kemudian. Syarat ibadah haji adalah selain kemampuan fisik, juga harus mampu secara finansial. secara finansial biaya Penyelenggaraan Ibadah Haji (BPIH) tiap tahun bertambah.
Mengingat biaya pendaftaran haji yang cukup mahal, maka saat ini beberapa Bank Syari'ah yang merupakan lembaga intermediating (penghubung antara masyarakat yang kekurangan dana dengan masyarakat yang kelebihan dana) memainkan peran sosialnya yaitu menawarkan produk-produk yang bertujuan untuk membantu nasabah yang ingin mendapatkan porsi haji lebih awal meskipun belum memiliki cukup uang. 
Produk tersebut dinamai Dana Talangan Haji. Produk inilah, yang dinilai menjadi pemicu panjangnya antrean daftar tunggu (waiting list) haji.

Program Dana Talangan Haji merupakan pelaksanaan terhadap fatwa DSN-MUI No.29/DSN-MUI/VI/2002 yang mengatur tentang Pembiayaan Pengurusan Haji LKS. Di dalam fatwa ini diatur mengenai kebolehan LKS untuk membantu menalangi pembayaran BPIH nasabah dengan menggunakan akad qard dan juga bisa mendapatkan ujrah atas jasa pengurusan porsi haji dengan menggunakan prisip ijarah.

Ketentuan DSN-MUI yang menetapkan akad qard untuk Dana Talangan Haji menimbulkan kontroversi, dan tidak memberikan keuntungan kepada bank maupun LKS. Hal ini karena qard merupakan akad tabaru' yang tidak membolehkan mengambil keuntungan dari sana. Meskipun DSN-MUI mensyaratkan pengambilan ujrah tidak boleh sebanding dengan jumlah talangan yang diberikan, dalam praktiknya, beberapa bank syari'ah dalam mengambil ujrah disesuaikan dengan talangan yang diberikan, seperti yang dilaksanakan oleh Bank Syari'ah Mandiri Cabang Malang. Semakin besar talangan yang diberikan oleh bank, semakin besar pula ujrah yang harus dibayar oleh nasabah (Nur Uyun, 2010:80). Hal ini merupakan penyimpangan dari fatwa DSN-MUI No.29/DSN-MUI/VI/2002 yang mensyaratkan ujrah tidak boleh sebanding dengan jumlah talangan yang diberikan.

Berbeda dengan Bank Syari'ah Mandiri di atas, menurut pendapat Bapak
Masjupri, salah satu DPS BPRS Dana Mulia Surakarta, Pembiayaan Rakyat Syari'ah yang ada di Surakarta, yaitu Bank Pembiayaan Rakyat Syari'ah (BPRS) Dana Mulia yang berlokasi di Jl. KH. Agus Salim No.10 Surakarta menggunakan akad ijarah multijasa dalam memberikan Dana Talangan Haji bagi nasabahnya. Prosesnya adalah pihak bank memberikan jasa pengurusan dan pendampingan mulai dari pendaftaran ke Kemenag, pengurusan sampai kepada pemberangkatan. Dengan jasa ini, pihak bank akan mendapatkan ujrah yang nominalnya telah ditentukan di awal pada saat kontrak disepakati. Dengan menggunakan akad ijarah multijasa, maka bank berhak menerima keuntungan berupa ujrah atas jasa yang diberikan, berbeda dengan akad qard.

Berdasarkan uraian diatas, penulis tertarik untuk melakukan penelitian lebih lanjut mengenai Akad Dana Talangan Haji dengan mengamati langsung bagaimana pelaksanaan pembiayaan Talangan Haji di BPRS Dana Mulia dan bagaimana kesesuaian praktiknya.

\section{Pengertian Pembiayaan Talangan Haji} Pembiayaan talangan haji adalah dana yang diberikan oleh LKS kepada calon jamaah haji untuk memenuhi persyaratan minimal setoran awal BPIH, sehingga ia bisa mendapatkan porsi haji sesuai dengan ketentuan kementerian Agama. Dana ini akan dikembalikan oleh jamaah sesuai dengan perjanjian (akad) yang sudah disepakati antara LKS dengan calon jamaah haji (Hadi, dan Widyarini, 2011). 
Dewan Syariah Nasional dan Majlis Ulama Indonesia pada tanggal 15 Rabi'ul Akhir $1423 \mathrm{H}$ atau bertepatan dengan tanggal 26 juni 2002 M, menetapkan fatwa DSN-MUI No 29/DSNMUI/III/2002 tentang pembiayaan pengurusan haji LKS. Dalam fatwa tersebut dinyatakan bahwa ketentuan pembiayaan pengurusan haji lembaga keuangan syariah adalah sebagai berikut:

1. Dalam pengurusan haji bagi nasabah, LKS dapat memperoleh imbalan ujrah (jasa) dengan menggunakan prinsip alijarah sesuai fatwa DSN-MUI No. 9/DSN-MUI/IV/2000.

2. Apabila diperlukan, LKS dapat membantu menalangi pembayaran BPIH nasabah dengan menggunakan prinsip al-qard sesuai dengan Fatwa DSN-MUI No. 19/DSNMUI/IV/2001.

3. Jasa pengurusan haji yang dilakukan LKS tidak boleh dipersyaratkan dengan pemberian talangan haji.

4. Besar imbalan jasa al-ijarah tidak boleh didasarkan pada jumlah talangan yang diberikan LKS kepada nasabah.

\section{Akad yang digunakan dalam Talangan Haji}

1. Qard

Qard secara bahasa adalah potongan, sedangkan menurut syar'i ialah menyerahkan uang kepada orang yang bisa memanfaatkannya, kemudian ia meminta kembaliannya sebesar uang tersebut (Al Jazairi, 2009:544). Qard adalah pemberian harta kepada orang lain yang dapat ditagih atau diminta kembali atau dengan kata lain meminjamkan tanpa mengharapkan imbalan (Syafi'i Antonia, 2007:131).

Dalam literatur fiqh klasik, qard dikategorikan dalam 'aqad tatawu' $i$ atau akad saling bantumembantu dan bukan transaksi komersial. Qard diberikan untuk nasabah yang memerlukan dana untuk keperluan mendesak dengan kriteria tertentu dan bukan untuk kegiatan konsumtif (Tim Pengembangan Perbankan Syariah Institut Bankir Indonesia, 2003:218).

\section{Ijarah}

Al-ijarah berasal dari kata alajru yang arti menurut bahasanya ialah al- iwad yang arti dalam bahasa indonesianya ialah ganti dan upah (Rahman, 2010:277). Dewan Syariah Nasional mendefinisikan ija\}>rah sebagai akad pemindahan hak guna (manfaat) atas suatu barang atau jasa dalam waktu tertentu melalui pembayaran sewa atau upah, tanpa diikuti dengan pemindahan kepemilikan barang itu sendiri (DSNMUI, 2006:55). Dengan demikian, dalam akad ija>rah tidak ada perubahan kepemilikan, tetapi hanya perpindahan hak guna saja dari yang menyewakan kepada penyewa (Ghazaly, 2010:277).

\section{METODE PENELITIAN}

Jenis penelitian ini adalah penelitian lapangan. Dalam penelitian ini, penulis melakukan penelitian secara langsung di lokasi penelitian untuk mengetahui secara langsung bagaimana praktik pembiayaan Dana Talangan Haji 
di BPRS Dana Mulia Surakarta. Sumber data yang penulis perlukan dalam penelitian ini yaitu: Sumber data primer adalah wawancara terhadap pengurus BPRS Dana Mulia. Sumber data sekunder, yaitu dokumen-dokumen, fatwa DSNMUI No.29/ DSN-MUI/VI/2002, bukubuku, Alquran, hadits, kitab-kitab fiqh, website, makalah, brosur artikel serta tulisan-tulisan lain yang secara langsung atau tidak langsung berkaitan dengan akad-akad muamalah khususnya akad yang digunakan dalam Dana Talagan Haji. Teknik pengumpulan data dalam penelitian ini dilakukan dengan cara observasi wawancara, dan dokumentasi.

Metode yang digunakan dalam penelitian ini adalah metode deskriptif kualitatif yaitu menggambarkan pada masalah yang diteliti. Penelitian ini mengarah pada pendeskripsian mengenai gambaran kondisi yang sebenarnya terjadi di lapangan dengan melakukan penelitian dan pengamatan terhadap pelaksanaan pembiayaan Dana Talangan Haji oleh BPRS Dana Mulia.

Dalam menganalisis data, penulis menggunakan metode analisis interaktif dengan menerapkan metode Miles dan Huberman, yaitu reduksi data, penampilan data, kemudian penarikan kesimpulan. Reduksi data merupakan proes seleksi data yang diartikan sebagai proses pemilihan, pemusatan perhatian pada penyederhanaan, pengabstrakan dan transformasi data kasar yang muncul dalam catatan tertulis di lapangan. Langkah selanjutnya adalah penampilan data. Data-data dirancang guna menggabungkan informasi yang tersusun dalam suatu bentuk yang mudah dipahami. Langkah selanjutnya adalah penarikan kesimpulan. Dalam hal ini peneliti berusaha menarik kesimpulan dari reduksi data dan penyajian data. Untuk uji keabsahan data, penulis menggunakan metode review informan, juga metode triangulasi data (pemeriksaan keabsahan data dengan memanfaatkan apa yang ada di luar data, sebagai pembanding).

\section{HASIL DAN PEMBAHASAN}

PT BPRS Dana Mulia selama ini dalam memberikan pembiayaan dana talangan haji menggunakan akad ijarah multijasa. Pembiayaan multijasa yaitu pembiayaan yang diberikan oleh Lembaga Keuangan Syari'ah (LKS) kepada nasabah dalam memperoleh manfaat atas suatu jasa.

Ijarah secara bahasa bisa diartikan dengan bai' al-quwwah (upah mengupah) atau disebut juga sewa jasa/tenaga. Dengan demikian, ijarah multijasa adalah akad ijarah (akad sewa/jasa) yang diterapkan untuk keperluan apa saja, sepanjang termasuk kategori jasa.

PT. BPRS Dana Mulia dalam pembiayaan dana talangan haji dengan akad ijarah multijasa mengambil ujrah sebagai keuntungan. Ketentuan tentang ujrah atau fee pada pembiayaan multijasa menurut fatwa DSN-MUI NO. 44/DSNMUI/VIII/2004 adalah besarnya ujrah atau fee harus disepakati diawal dan dalam bentuk nominal bukan prosentase. PT BPRS Dana Mulia dalam mengambil ujrah di tentukan dan disepakati diawal bersama nasabah dan disebutkan berupa nominal sejumlah uang, bukan prosentase. 
Berdasarkan fatwa DSN-MUI NO. 44/DSN-MUI/VIII/2004 yang menyebutkan besarnya ujrah atau fee harus disepakati diawal dan dalam bentuk nominal bukan prosentase, maka dapat disimpulkan pengambilan ujrah oleh PT BPRS Dana Mulia sudah sesuai dengan fatwa DSN-MUI NO. 44/DSNMUI/VIII/2004.

Besar nominal ujrah yang diambil oleh PT. BPRS Dana Mulia berdasarkan pada jumlah dana talangan haji yang diberikan pada nasabah dan berapa lama waktu pelunasan yang diperlukan. Semakin besar dana yang diberikan, semakin lama waktu pelunasan, maka ujrah yang harus dibayar oleh nasabah juga semakin besar. Besaran ujrah dinyatakan dalam bentuk nominal, ditawarkan kepada nasabah untuk mencapai kesepakatan.

Pengambilan ujrah pada PT BPRS

Dana Mulia seperti diuraikan diatas sudah sesuai dengan fatwa DSN-MUI NO. 44/DSN-MUI/VIII/2004. Disini peneliti juga akan menguraikan dengan al Qur'an dan hadits.

Pada BPRS Dana Mulia, besar ujrah yang diambil disesuaikan dengan jumlah talangan yang diberikan serta jangka waktu pelunasan. Meskipun besarnya ujrah yang diambil sesuai dengan kesepakatan, namun hal ini bisa dikatakan sebagai riba.

Ujrah yang ditentukan berdasarkan dengan besarnya dana talangan dan waktu jatuh tempo bisa dikategorikan sebagai riba yaitu riba nasi'ah (Khilmini, 2010:77). Riba nasi'ah menurut Satria Efendi sebagaimana dikutip oleh Ghazaly
(2010:218-219) adalah tambahan pembayaran atas jumlah modal yang disyaratkan lebih dahulu yang harus dibayar oleh si peminjam kepada yang meminjam tanpa risiko sebagai imbalan dari jarak waktu pembayaran yang diberikan kepada si peminjam. Dalam riba ini terkandung tiga unsur, yaitu:

1. Adanya tambahan pembayaran atau modal yang dipinjamkan

2. Tambahan itu tanpa risiko kecuali sebagai imbalan dari tenggang waktu yang diperoleh si peminjam.

3. Tambahan itu disyaratkan dalam pemberian piutang dan tenggang waktu.

Melihat beberapa hal di atas, pengambilan ujrah berdasarkan besarnya dana talangan haji tidak tepat. Misalnya bapak A mengajukan pembiayaaan dana talangan haji 20 juta untuk satu orang dibandingkan bapak B mengajukan 60 juta untuk 5 orang keluarganya. Tentu dalam hal ini tidak ada risiko yang berbeda. Dalam hal ini yang ada adalah jasa untuk mengurus biaya haji bapak B lebih rumit karena banyak orang. Maka PT BPRS Dana Mulia boleh mengambil ujrah pada bapak B lebih besar daripada bapak A tetapi berdasarkan tingkat kesulitan dan pengorbanan jasa yang dikeluarkan oleh karyawan PT BPRS Dana Mulia.

Dari uraian diatas, pengambilan ujrah berdasarkan jumlah dana talangan haji yang diberikan tidaklah tepat. Karena dalam akad ijarah multijasa, yang dijadikan dasar adalah pengorbanan jasa yang diberikan pada nasabah, sedangkan besar kecilnya dana yang diberikan jika 
dijadikan landasan pengambilan ujrah adalah termasuk riba nasi'ah karena tidak ada risiko yang ditimbulkan.

Namun, apabila tambahan itu tidak disyaratkan dalam akad, tetapi merupakan sumbangan sukarela dari si peminjam/nasabah. Hal ini disunnahkan dalam Islam, sesuai dengan hadis rasulullah dari Abu Nu'aim dari Sufyan dari Salamah dari Abi Salamah dari Abi Hurairah r.a:

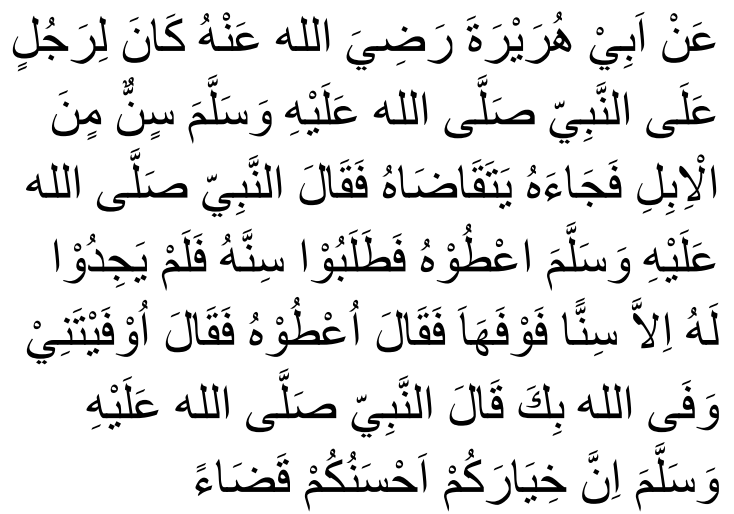

Artinya:

Dari Abu Hurairah r.a, ia berkata: "Nabi mempunyai hutang kepada seseorang, (yaitu) seekor unta dengan usia tertentu. Orang itupun datang menagihnya. (Maka) beliaupun berkata, "Berikan kepadanya" kemudian mereka mencari yang seusia dengan untanya, akan tetapi mereka tidak menemukan kecuali yang lebih berumur dari untanya. Nabi (pun) berkata: "Berikan kepadanya", Dia pun menjawab, "Engkau telah menunaikannya dengan lebih. Semoga Allah SWT membalas dengan setimpal". Maka Nabi SAW bersabda, "Sebaik-baik kalian adalah orang yang paling baik dalam pengembalian (hutang)".
Hadis di atas menunjukkan anjuran rasulullah untuk memberikan pembayaran hutang dengan lebih baik, dalam arti dilebihkan secara sukarela. Bukan disesuaikan dengan jumlah talangan dan lama waktu pelunasan.

Sedangkan pengambilan ujrah berdasarkan jangka waktu pelunasan, hal ini sesuai dengan yang dikemukakan Satria Efendi dalam Ghazaly (2010), bahwa adanya tambahan itu disyaratkan dalam pemberian piutang karena adanya tenggang waktu maka itu adalah riba. Dalam hal ini riba nasi'ah.

Berbeda ketika jumlah ujrah yang diambil oleh BPRS tidak didasarkan pada jumlah talangan maupun jangka waktu pelunasan. Baik talangan yang diberikan itu 20 juta maupun 60 juta, waktu pelunasan tujuh tahun maupun dua tahun, ujrah yang diambil misalnya lima juta. Ditetapkan di awal sesuai kesepakatan. Jasa pengurusan haji tidak dikaitkan dengan berasr jumlah dana talangan yang diberikan dan lamanya waktu pengembalian, tetapi berdasarkan jasa dan pengorbanan yang diberikan oleh PT BPRS Dana Mulia.

Ujrah besar untuk talangan kecil pun tidak jadi masalah ketika sudah sesuai kesepakatan karena ujrah tidak bergantung terhadap jumlah talangan. BPRS harus berani mengambil langkah demikian sehingga praktek pembiayaan pun terlaksana sesuai ketentuan syari'at. Melihat uraian di atas, dari sisi ujrah, peneliti berpendapat bahwa pembiayaan yang dilaksanakan oleh BPRS Dana Mulia, dalam pengambilan ujrah masih belum sesuai syariat. 


\section{KESIMPULAN}

Pelaksanaan Pembiayaan Talangan Haji PT BPRS Dana Mulia menggunakan akad ijarah multijasa, yaitu akad ijarah (akad sewa/jasa) yang diterapkan untuk keperluan apa saja, sepanjang termasuk kategori jasa. PT. BPRS Dana Mulia menggunakan akad ijarah multijasa berdasar pada fatwa No. 44/DSNMUI/VIII/2004 tentang Pembiayaan Multijasa.

Ditimbang dari fatwa No. 29/DSNMUI/III/2002 tentang pembiayaan pengurusan haji LKS, secara teknis, akad yang digunakan oleh PT. BPRS Dana Mulia tidak sesuai dengan fatwa tersebut karena yang menjadi ketentuan dalam fatwa itu adalah menggunakan akad qard dan ijarah. Namun, secara substansi, pembiayaan multijasa yang dilaksanakan oleh PT. BPRS Dana Mulia sama dengan apa yang difatwakan DSN-MUI karena adanya talangan yang diberikan serta adanya jasa pengurusan haji. Ketidaksesuaian dengan fatwa ada pada ujrah yang diambil. Dalam fatwa DSNMUI No. 29/DSN-MUI/III/2002 ada ketentuan pengambilan ujrah tidak boleh didasarkan pada pemberian talangan yang diberikan. Dalam praktiknya, di PT. BPRS Dana Mulia, besar ujrah yang diambil didasarkan pada jumlah talangan yang diberikan serta lama waktu pelunasan.

\section{DAFTAR PUSTAKA}

Al-Imam al-'Allamah Badruddin Abi Muhammad Mahmud bin Ahmad Al-'Aini, Tt, 'Umdah Al-Qari
Syarkhu sahih al-Bukhari. Beirut: Dar Al-Fikr

Al Jazairi, Abu Bakr. 2009. Minhajul Muslim. Jakarta: Darul Falah. Terjemahan Fadhli Bahri

DSN-MUI dan BI. 2006. Himpunan Fatwa Dewan Syariah Nasional.

Ghazaly, Abdul Rahman. 2010. Fiqh Muamalat. Jakarta: Kencana Prenada Media Group

Hadi, Syamsul dan Widyarini. 2011. Dana Talangan Haji, Fatwa DSN dan Praktek di LKS. Yogyakarta. Jurnal As-Syir'ah. Vol.45, No.II, 2011, hlm. 1473.

Khilmini, 2010. Pelaksanaan Pembiayaan Talangan Haji di Bank Syari'ah Mandiri Semarang (Relevansinya dengan Fatwa DSN-MUI No. 29/DSN-MUI/III/2002 Tentang Pembiayaan Pengurusan Haji $L K S)$. Skripsi, tidak diterbitkan. Fakultas Syari'ah IAIN Walisongo Semarang

Nur Uyun. 2010. Analisis Manajemen Pembiayaan Dana Talangan Haji Pada PT. Bank Syari'ah Mandiri Cabang Malang. Skripsi, tidak diterbitkan, Fakultas Ekonomi UIN Malang. Malang.

Rahman, Abdul. dkk, 2010. Fiqh Muamalat. Jakarta: Kencana Prenada Media Group 
Syafi'i Antonio, Muhammad. 2007. Bank Syariah dari Teori ke Praktik. Jakarta: Gema Insani

Tim Pengembangan Perbankan Syariah Institut Bankir Indonesia. 2003. Konsep, Produk dan Implementasi Operasional Bank Syariah. Jakarta: Djambatan 